\title{
Analysis of electronic educational resources for distance learning
}

\author{
Olga Katkova $^{1 *}$, Mariia Mukhina ${ }^{1}$, Zhanna Chaykina $^{1}$, Zhanna Smirnova $^{1}$, and Tatyana \\ Tsapina $^{2}$ \\ ${ }^{1}$ Minin Nizhny Novgorod State Pedagogical University, Department of Technology of Service and \\ Technological Education, Nizhny Novgorod, Russia \\ ${ }^{2}$ Lobachevsky State University of Nizhny Novgorod (UNN), Department of Firm Economics, Nizhny \\ Novgorod, Russia
}

\begin{abstract}
This article analyzes modern trends of educational processes stipulated by features of modern society development. Modifications in surrounding reality dictate necessity of updating the learning process towards active transition to distance education. Increased demand of students for electronic educational resources stipulated necessity to analyze representation of electronic platforms and identification of their features. This work is aimed at analysis of the electronic educational resources being most popular among students, and identification of features of their use in distance education. The study was performed using analysis of scientific publications devoted to the research subject, survey and results of its analysis, analysis of electronic educational resources aiming at identification of their features for distance education. This work is comprised of two stages. At the first stage, the students of two learning levels were surveyed (universal bachelor degree course and high school), which allowed to reveal common requirements for the two levels of preparation for electronic educational resources and features of their selection by respondents. At the second stage, the most demanded for distance learning electronic educational platforms and their resources were analyzed to assist teacher to develop algorithm of combination of various electronic resources in the frames of content of certain course. A teacher should be aware of the content of the most popular educational platforms of opensource information educational environment, determine reasonability of access to this or that electronic resource and promote students to active participation in distance form.
\end{abstract}

Keywords: distance education, electronic information and educational environment, electronic educational platform, electronic educational resources.

\section{Introduction}

Current conditions of society development place new demands on educational environment $[1,2,3]$. While considering the educational environment as the established psychological

\footnotetext{
* Corresponding author: katkova.ov@yandex.ru
} 
and pedagogical reality, a set of established conditions for students' education [4], it should be mentioned that these conditions are rapidly changing under the action of various factors: social, psychological, epidemiological, etc. One of the vectors of these changes is aimed at inclusion of distance learning into educational processes of various level [5, 6]. Development of the distance learning in Russia was initiated several years ago; however, it is not yet possible to talk about a sustainable system [7, 8]. Searching for new ways and tools of high-quality distance learning is under way $[9,10,11]$. This is confirmed by numerous scientific theoretical and practical studies being performed nowadays [12-17].

This work is aimed at analysis of the electronic educational resources being most popular among students, and identification of features of their use in distance education.

The research objectives are as follows:

1.To analyze the use of educational environment by students in distance learning.

2.To identify opportunities of the electronic educational resources for distance learning being most popular among students.

\section{Methods}

This study was carried out using analysis of scientific publications devoted to the research subject, survey and results of its analysis, analysis of electronic educational resources.

\section{Results}

This study was comprised of two stages. At the first stage, the students of two learning levels were surveyed. The first group included the first-year students of universal bachelor course (60 persons), the second group included students of 10-11 grades of comprehensive schools (50 persons). The survey results are summarized in Table 1.

Table 1. Results of survey about selection of electronic resources in distance learning.

\begin{tabular}{|c|c|c|}
\hline \multirow{2}{*}{$\begin{array}{l}\text { Key components of the } \\
\text { survey }\end{array}$} & \multicolumn{2}{|c|}{ Survey results in students' groups } \\
\hline & $\begin{array}{l}\text { First-year students of universal } \\
\text { bachelor course }\end{array}$ & $\begin{array}{l}\text { 10-11 grade students of } \\
\text { comprehensive schools }\end{array}$ \\
\hline $\begin{array}{l}\text { 1. Aims of the use of } \\
\text { educational resources }\end{array}$ & \multicolumn{2}{|c|}{ 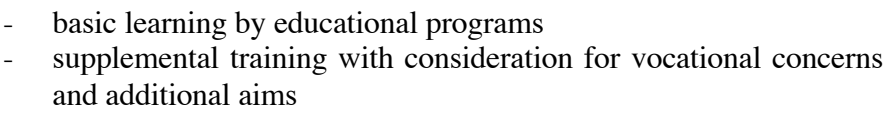 } \\
\hline $\begin{array}{l}\text { 2. Electronic educational } \\
\text { resources and } \\
\text { platforms used in } \\
\text { distance learning } \\
\text { (according to the } \\
\text { aims): } \\
\text { basic learning by } \\
\text { educational programs; }\end{array}$ & $\begin{array}{l}\text { - Electronic information and } \\
\text { educational environment of } \\
\text { own higher education } \\
\text { institution: } 100 \%\end{array}$ & $\begin{array}{ll}\text { - } & \text { Uchi.ru (https://uchi.ru/): } \\
70 \% & \text { diary } \\
\text { - } & \text { Electronic } \\
\text { (https://dnevnik.ru/): } 90 \% \\
\text { - } & \text { Russian electronic school } \\
& \text { (https://resh.edu.ru/): } 60 \% \\
\text { - } & \text { Video lessons } \\
& \text { (https://videouroki.net/): } \\
40 \% & \end{array}$ \\
\hline
\end{tabular}




\begin{tabular}{|c|c|c|}
\hline $\begin{array}{l}\text { supplemental training } \\
\text { with consideration for } \\
\text { vocational concerns } \\
\text { and additional aims }\end{array}$ & $\begin{array}{l}\text { - } \begin{array}{l}\text { National platform of } \\
\text { opensource education } \\
\text { (https://openedu.ru/): } 10 \%\end{array} \\
\text { - } \begin{array}{l}\text { Coursera } \\
\text { (https://www.coursera.org/): }\end{array} \\
5 \% \\
-\quad \begin{array}{l}\text { Lektorium } \\
\text { (https://www.lektorium.tv/m } \\
\text { ooc): } 5 \%\end{array}\end{array}$ & $\begin{array}{l}\text { - Sdam GIA: Reshu VPR } \\
\text { (https://vpr.sdamgia.ru/): } \\
100 \%\end{array}$ \\
\hline 3. Expected result & $\begin{array}{l}\text { mastering knowledge of the } \\
\text { disciplines in respective areas } \\
\text { of training during distance } \\
\text { learning: } 90 \% \\
\text { - improvement of education } \\
\text { level: } 70 \% \\
\text { - results of formation of } \\
\text { students' portfolio: } 20 \% \\
\text { obtaining of education } \\
\text { certificates: } 15 \%\end{array}$ & 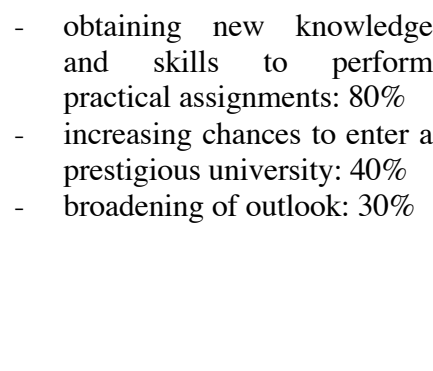 \\
\hline 4. Difficulties & \multicolumn{2}{|c|}{ 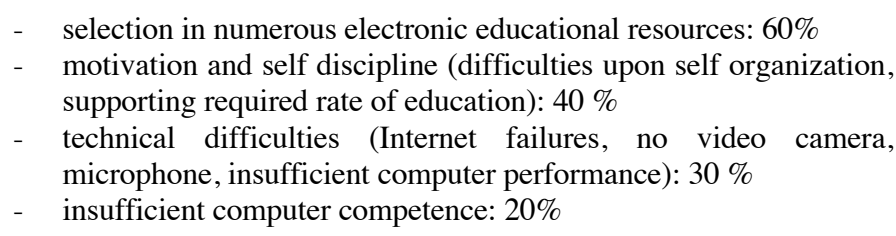 } \\
\hline $\begin{array}{l}\text { 5. Advantages and } \\
\text { emerging } \\
\text { opportunities }\end{array}$ & \multicolumn{2}{|c|}{$\begin{array}{l}\text { - freedom in planning the time and place of learning: } 90 \% \\
\text { - } \text { selection of individual learning rate: } 50 \% \\
\text { - } \text { obtaining of education certificates: } 10 \% \\
\text { - selection of supplemental courses depending on student's } \\
\text { interests: } 10 \%\end{array}$} \\
\hline $\begin{array}{l}\text { 6. Independence level } \\
\text { upon selection of } \\
\text { electronic resources }\end{array}$ & $\begin{array}{l}\text { - } \quad \text { recommendations by teacher: } \\
90 \% \\
\text { - } \quad \text { independent selection: } 40 \%\end{array}$ & $\begin{array}{l}\text { - } \text { recommendations } \\
\text { teacher: } 100 \% \\
\text { - independent selection: } 10 \%\end{array}$ \\
\hline
\end{tabular}

On the basis of survey results, it is possible to arrive at the following conclusions:

1. Common for both levels of learning:

- aims of the use of electronic resources. The main aim was the basic learning by educational programs;

- upon selection of electronic resources for distance learning, teachers' recommendations prevailed;

- freedom in planning the time and place of learning;

- selection of individual learning rate; obtaining of education certificates;

- selection of supplemental courses depending on student's interests.

2. Features of selection of electronic resources in distance learning for each learning level:

- various educational platforms and electronic educational courses; 
- expected results of use of electronic educational resources. For students of bachelor courses, in addition to mastering disciplines in selected field during distance learning, the expected results include improvement of learning level, formation of students' portfolio, obtaining education certificates. Students of high school using educational resources expected to obtain new knowledge and to develop skills to perform practical assignments; to increase chances to enter a prestigious university, to broaden their outlook.

The second stage was aimed at analysis of opportunities of online courses of electronic educational environment for distance learning of both categories of students. With this aim, the online resources were selected determined as preferential by students according to survey results.

All students of higher education institutions for basic learning by educational programs select for distance learning the electronic resources offered by universities at their educational platforms $[18,19,20]$. Such educational resources are available, user friendly, and provide teacher to student feedback.

The second position in terms of popularity among students of bachelor courses is occupied by the National platform of opensource education (https://openedu.ru/), which provides free of charge opportunity to study the courses of leading Russian universities (641 courses) $)^{\dagger}$. Among others, they are comprised of the courses of Lomonosov Moscow State University (42 courses), Higher School of Economics (100 courses), Peter the Great St. Petersburg Polytechnic University (74 courses) and others. The advantage of the courses is their opensource form, simple registration and enrolling in a course, feedback, opportunity to join a course after its beginning. Students after passing the courses of National platform of opensource education highlight their high efficiency, interesting and substantial content, assistance by course organizers, technical support.

For supplemental learning concerning vocational concerns and additional aims, the students use opensource electronic platform Coursera (https://www.coursera.org/). The platform provides opportunity to study courses of leading world universities. However, the main difficulty to study the courses at Coursera for students from Russia is the English content of the courses. Some courses are accompanied by Russian subtitles. The second feature of the Coursera platform is paid courses.

An advantage of Lektorium platform (https://www.lektorium.tv/mooc) is opportunity to start learning at the courses at any time. The platform provides more than 100 online courses, numerous media resources presented in the form both of separate video lectures and of lecture series, proceedings of conferences. Students expressed interest in such courses of Lektorium as "Design of information in presentations", "Presentations". These courses proved to be useful for development of skill of providing information in the form of presentation, highly required under conditions of distance learning.

Survey of high school students (grades 10-11) demonstrated that selection of electronic educational resources for distance learning was stipulated by teachers' recommendations. The most popular platform for learning was Uchi.ru (https://distant.uchi.ru/): a Russian online platform, where students from all regions of Russia studied school subjects in interactive form. This platform presents school materials for grades 1-11 for all general educational subjects. The platform provides a set of free of charge services: interactive assignments, video classes, home and testing works, statistics of student's achievements and translation of online classes with teachers, paid content is also available.

The second position in terms of popularity is occupied by electronic educational platform for secondary schools: Dnevnik.ru (https://dnevnik.ru/). Dnevnik.ru provides the following services of distance learning: testing in electronic form, exchange with comments to homework, school announcements, news, storing grade files, library and media content

\footnotetext{
${ }^{\dagger}$ National opensource education platform. https://openedu.ru/
} 
of ready educational materials. Organization of learning using this platform provides possibility for parents to control student's achievements.

Russian E-School (RES) (the third electronic platform in terms of popularity among the surveyed persons) is one of the most intensively developing electronic educational platforms for students. RES is the complete school course; this is information and educational environment combining student, teacher, parent. It presents not only educational resources for main education, but also supplemental content: materials for extended education, information about competitions, catalog of museums, etc.

Sufficiently popular supplemental platform for distance learning of senior school students is an educational portal of preparation to testing works: Sdam GIA: Reshu VPR (https://vpr.sdamgia.ru/). An advantage of this resource for students is availability of numerous variants of testing works on school subjects.

\section{Discussion}

The issue of election and efficient use of online resources of electronic educational environment of distance learning is very important.

Analysis of this aspect has demonstrated that the electronic educational environment is comprised of a wide range of online courses available for students. A teacher should arrange such system of distance learning, which will be sufficiently mobile to be used by students of various learning levels, to provide feedback, allow visualization of learning results at each stage, provide reflection and correction of individual educational route for each student.

\section{Conclusion}

Selection of electronic educational resources for organization of distance learning is the key stage for provision of education efficiency in this format. Taking into account that the development of distance learning is not completed, each educational entity selects its route of distance learning. Theoretical and empirical studies in this field are under way.

However, already at this stage of development of distance learning it is obvious that certain algorithm of arrangement of distance learning in educational entity should be discussed. In addition, it is required to discuss technical, psychological and pedagogical, methodological conditions of distance learning organization at all learning levels.

\section{References}

1. M.V. Mukhina, E.S. Mukhina, Innovatsionnaya ekonomika: perspektivy razvitiya i sovershenstvovaniya, 6(40), 57-64 (2019)

2. H. Aldowah, H. Al-Samarraie, W. Mohamad Fauzy, Telematics and Informatics, 37, 13-49 (2019)

3. V.G. Gerasimova, M.R. Melamud, M.Yu. Sorokina, Printsipial'nyye Voprosy Obucheniya V Elektronnoy Obrazovatel'noy Srede [Principal issues of education in the electronic educational environment], in Scientific and educational space: development prospects: materials of the VI International scientific-practical conference, 13 August 2017, Cheboksary, Russia (2017). https://doi.org/10.21661/a422

4. S.G. Mkrtchyan, Molodoy uchenyy, 45(283), 338-340 (2019) 
5. E. Gryaznova et al., Azimuth of Scientific Research: Pedagogy and Psychology, 8(4(29)), 63-65 (2019)

6. N.C. Burbules, G. Fan, Ph. Repp, Geography and Sustainability, 1(2), 93-97 (2020)

7. M.V. Mukhina, A.S. Pletneva, Informatization of the education process. In the collection: Social and technical services: problems and ways of development, in Collection of articles based on the materials of the II All-Russian scientific and practical conference, 253-256 (NNSPU named after K. Minin, N.Novgorod, 2015)

8. G.V. Akhmetzhanova, D.R. Abieva, Azimuth of Scientific Research: Pedagogy and Psychology, 3(28), 28-31 (2019)

9. O.I. Vaganova, E.A. Aleshugina, K. A. Maksimova, Azimuth of Scientific Research: Pedagogy and Psychology, 8(3(28)), 57-59 (2019)

10. C.E. Paterson, N. Paterson, W. Jackson, F. Work, Nurse Education Today, 85, 104236 (2020)

11. I. Srba, M. Savic, M. Bielikova, M. Ivanovic, C. Pautasso, Computers \& Education, 135, 75-90 (2019)

12. V. Kovanovich et al., The Internet and Higher Education, 40, 20-43 (2019). https://doi.org/10.1016/j.iheduc.2018.09.001

13. A.J. Scheerder, A.J.A.M. van Deursen, J.A.G.M. van Dijk, Poetics, 80, 101426 (2020). https://doi.org/10.1016/j.poetic.2019.101426

14. N.P. Bakharev, Azimuth of Scientific Research: Pedagogy and Psychology, 8(3(28)), 35-39 (2019)

15. 5 krupneyshikh platform onlayn-obucheniya [The five largest online learning platforms. The largest educational platforms are collected in the review of RIAMO. Accessed on: December 20, 2020. [Online]. Available: https://riamo.ru/article/231962/5-krupnejshih-platform-onlajnobucheniya.xl?mTitle $=\& \mathrm{mDesc}=\& \mathrm{mImg}$

16. V. Kovanović, S. Joksimović, O. Poquet, T. Hennis, D. Gašević, The Internet and Higher Education, 40, 20-43 (2019)

17. J. van Dijck, Computer Law \& Security Review, 36, 105377 (2020)

18. B.Kh. Joraev, M.A. Pakhmutova, Herzen's Readings: Psychological Research in Education, 2, 306-312 (2019)

19. Yu.F. Katkhanova, D.D. Avetisyan, D.Yu. Kirilov, "Cloudy” portal in the electronic educational environment, in Scientific research: from theory to practice: materials of the IX International scientific-practical conference, 10 July 2016, Scientific Cooperation Center Interactive plus, Cheboksary, 98-102 (2016)

20. M.N. Bulaeva, O.I. Vaganova, M.I. Koldina, A.V. Lapshova, A.V. Khizhnyi, Advances in Intelligent Systems and Computing, 622, 406-411 (2018) 